INTEGRITAS : Jurnal Pengabdian

Vol 5 No 1 Juli 2021

ISSN 2580 - 7978 (cetak) ISSN 2615 - 0794 (online)

\title{
PERENCANAAN KARIR DAN EVALUASI DIRI SISWA DI KOTA DILI NEGARA TIMOR LESTE
}

\section{CAREER PLANNING AND SELF EVALUATION STUDENT IN DILI CITY TIMOR LESTE COUNTRY}

\author{
Yanto Prasetyo \\ Fakultas Psikologi, Universitas 17 Agustus 1945 Surabaya \\ Email: yanto_prasetyo@untag-sby.ac.id
}

\begin{abstract}
Abstrak: Perencanaan karir adalah bagian dari pengembangan karir (career development). Untuk mencapai pengembangan maksimal, seseorang perlu memahami yang dimaksud dengan perencanaan karir terlebih dahulu. Perencanaan karir (career planning) adalah suatu proses dimana individu dapat mengidentifikasikan dan mengambil langkah-langkah untuk mencapai tujuan-tujuan karirnya. Hal ini seperti memahami potensi diri, minat, dan keadaan zaman yang terus berubah. Maka, dari itu diperlukan pengetahuan yang luas dan pengalaman yang banyak untuk mencapai hal tersebut. Penyuluhan ini dapat memberikan kesadaran para siswa di Dili, Timor Leste, untuk merencanakan dan menggapai karirnya setinggi mungkin. Siswa diajak untuk memiliki tujuan dalam hidupnya, memahami potensi dalam dirinya dan menyiapkan cara merealisasikan mimpinya. Agar kelak setelah mereka dewasa mereka memiliki kemampuan lebih untuk mengelola diri dan negaranya untuk lebih baik lagi.
\end{abstract}

Kata Kunci: Perencanaan karir, Pengembangan karir

Abstract: Career planning is a part of career development. To achieve maximum development, one needs to understand what is meant by career planning first. Career planning is a process by which individuals can identify and take steps to achieve their career goals. It is like understanding your potential, interests, and the changing circumstances of the times. Therefore, it requires extensive knowledge and a lot of experience to achieve this. This outreach can give awareness to students in Dili, Timor Leste, to plan and achieve a career as possible. Students are invited to have a goal in understanding, understanding their potential and preparing ways to realize their dreams. So that later when they grow up, they have more abilities for themselves and their country to be even better.

Keywords: Career planning, Career development

\section{PENDAHULUAN}

Perencanaan karir perlu disiapkan oleh setiap individu khususnya siswa pada tingkat akhir yang akan menyelesaikan masa studinya. Setiap Individu mendambakan kesuksesan kelak. Namun, hal ini tidak disertai dengan pemahaman mengenai pilihan karir oleh individu tersebut. Kegagalan dalam berkarir tidak hanya berdampak pada finansial, akan tetapi hal ini berpengaruh pada Kesehatan fisik maupun mental. Oleh sebab itu perlu diadakannya pemahaman mengenai perencanaan karir. Sukardi dalam (Felentini, dkk 2013) menjelaskan bahwa perencanaan karir adalah suatu proses 


\section{INTEGRITAS : Jurnal Pengabdian}

Vol 5 No 1 Juli 2021

ISSN 2580 - 7978 (cetak) ISSN 2615 - 0794 (online)

individu dalam memilih dan mentukan karir yang diinginkan. Perencanaan karir adalah bagian dari pengembangan karir (career development). Untuk mencapai pengembangan diri secara maksimal, seseorang perlu memahami yang dimaksud dengan perencanaan karirnya. Dewa Ketut Sukardi (2002:41) mengungkapkan dalam menetapkan pilihan karir ada beberapa bimbingan karir yang dapat membantu siswa. Bimbingan karir ini dapat dirinci sebagai berikut:

1. Pemantapan, pemahaman diri berkenaan dengan karir yang hendak dikembangkan.

2. Pemantapan orientasi dan informasi karir umumnya, khususnya karir yang dikembangkan.

3. Orientasi dan informasi terhadap dunia kerja dan usaha memperoleh penghasilan untuk memenuhi kebutuhan hidup.

4. Orientasi dan informasi terhadap pendidikan yang lebih tinggi, khususnya sesuai dengan karir yang hendak dikembangkan.

Perencanaan karir (career planning) adalah suatu proses dimana individu dapat mengidentifikasikan sehingga dapat mengambil langkah-langkah yang efektif untuk mencapai tujuan karirnya. Langkah awal yang harus dilakukan adalah memahami potensi diri, minat, dan ciri kepribadian yang dimilikinya. Oleh karenanya diperlukan pengetahuan yang luas dan penambahan wawasan untuk dapat mencapai tujuan.

Masyarakat dengan tingkat pendidikan yang rendah dan kurangnya wawasan di era sekarang ini akan mempengaruhi terhadap berkurangnya peluang dan kesempatan untuk berkompetisi dengan yang lainnya. Kondisi ini bisa dibuktikan dengan banyaknya warga masyarakat yang hanya mendapatkan peluang kerja di tingkat pelaksana dan bahkan banyak sekali warga masyarakat yang tidak mendapatkan kesempatan untuk mendapatkan peluang kerja sama sekali (pengangguran). Timor Leste adalah salah satu negara yang baru saja merdeka (20 tahun) dan termasuk Negara sedang berkembang sehingga wajar jika beberapa sarana dan pra sarana masih belum terbangun secara lengkap. Dengan perencanaan yang matang tentang karir, akan menjadikan proses pencapaian kepuasan dan kesuksesan dapat menjadi lebih mudah.

Tujuan untuk melakukan self evaluation dan career planning adalah siswa/i yang telah lulus dari SMA di seluruh kota Dili, Timor Leste. Hasil akhir yang diharapkan setelah terlaksananya program yaitu: siswa Timor Leste dapat mengembangkan potensi 


\section{INTEGRITAS : Jurnal Pengabdian}

Vol 5 No 1 Juli 2021

ISSN 2580 - 7978 (cetak) ISSN 2615 - 0794 (online)

diri dan alam yang dimiliki, serta mampu merancang karir yang sesuai dengan potensinya.

\section{METODE}

Metode pelaksanaan dalam pengabdian ini ialah dengan cara pelatihan. Menurut KBBI pelatihan adalah proses, cara, atau perbuatan melatih. Pengukuran psikologi digunakan untuk mengukur Self Evaluation pada siswa dalam kegiatan tersebut.

Pelaksanaan program pengabdian masyarakat di Timor Leste dengan kegiatan Career Planing and Self Evaluation. Terdapat beberapa langkah untuk pelaksanaanya sebagai berikut:

1. Tahap Awal

Pada tahap persiapan ini disiapkan keperluan untuk melakukan pengukuran psikologi guna mendapatkan gambaran tentang potensi diri, minat kerja serta karakteristik kepribadiannya. Selanjutnya menyiapkan materi tentang career planning yang nantnya akan disampaikan oleh narasumber. Peralatan yang disiapkan meliputi laptop, proyektor, sound system, materi penyuluhan. Ada pula penyiapan lembar absensi sebagai bukti kehadiran peserta self evaluation dan career planning yang akan dibagikan dan diisi oleh para siswa.

2. Tahap Inti

Pada tahap inti adalah tahap dimana diberikan penyuluhan yang disampaikan oleh narasumber dengan media slide powerpoint pada hari pertama kepada para siswa untuk kemudian pada hari kedua dilakukan pengukuran psikologi untuk mendapatkan gambaran tentang potensi, minat, dan karakter kepribadian siswa. Selain itu juga dilanjutkan dengan sesi interview kepada para siswa untuk mendapatkan gambaran lebih detail tentang keadaan diri.

3. Penutup

Pada tahap penutup, dilakukan analisis hasil pengukuran psikologi untuk kemudian dibuat laporan pelaksanaan kegiatan.

\section{HASIL DAN PEMBAHASAN}

Proses pengabdian masyarakat ini dilaksanakan selama 3 hari, pada tanggal 29 31 Januari 2019. Pengabdian masyarakat yang dikemas dalam bentuk seminar telah diikuti oleh 14 peserta, disesi awal peserta akan mengisi alat ukur psikologi yang disediakan, hal ini dimaksudkan untuk mengetahui gambaran tentang potensi diri, minat 


\section{INTEGRITAS : Jurnal Pengabdian}

Vol 5 No 1 Juli 2021

ISSN $2580-7978$ (cetak) ISSN 2615-0794 (online)

kerja serta karakteristik kepribadian setiap peserta seminar. Alat ukur yang telah diberikan kepada siswa selanjutnya akan dianalisis.

Career Planning dimulai dengan penyampaian materi dan melakukan proses eksplorasi dan informasi karir. Bardick dalam (Zaroh, 2018) menjelaskan bahwa tahap ini bertujuan untuk meningkatkan pemahaman siswa tentang kurangnya pemahamam siswa mengenai diri siswa yang disebabkan adanya kesenjangan antara bakat dan minat serta kesulitan untuk menentukan minat yang diinginkan oleh siswa. Ketidaksesuaian antar diri individu seperti ketidaksesuaian bakat dan minat yang dimungkinkan akan menghambat individu dalam memahami diriya secara utuh.

Dari hasil observasi terhadap siswa setelah penyampaian materi career planning dan melakukan self evaluation terdapat peningkatan tingkat percaya diri pada siswa, hal ini dapat dibuktikan dengan siswa yang cukup interaktif dalam menyelesaikan tugas self evaluation yang ditugaskan oleh narasumber. Siswa akan melakukan evaluasi diri dengan menggunakan analisis SWOT, kemudian dilanjutkan dengan menggambarkan perencanaan karir dalam kurung waktu 3 tahun mendatang. Hal ini dalam menuliskan perencanaan karir sebagai suatu cara untuk menambah rasa percaya diri pada siswa terhadap pilihan karir. Zaroh (2018) menjelaskan tujuan analisis SWOT untuk membantu siswa secara aktif dalam menentukan faktor internal dan eksternal yang dapat mendukung ataupun menghambat karir yang akan dilakukan oleh siswa

Setelah proses self evaluation dilakukan siswa akan mendapatkan kesempatan untuk menyebutkan apa yang menjadi kekurangan, kelebihan, dan ancaman dalam dirinya, kemudian menjelaskan tentang rencana karir dalam kurung waktu 3 tahun. Salah satu siswa berkenan untuk menjelaskan tentang career planning dan self evaluation yang telah dikerjakan, siswa menjelaskan bahwa individu menjalaskan bahwa akan berkarir di bidang jurnalistik. Individu menjelaskan yang menjadi kekuatan untuk mendukung individu dalam berkarir sebagai berikut memiliki kemampuan menulis yang baik, fleksibel dan mampu beradaptasi dengan cepat, memiliki rasa ingin tahu yang tinggi. Kemudian kelemahan yang dimiliki individu adalah kurang mampu dalam memanajemen waktu, tidak memahami tentang videografi dan fotografi. Selanjutanya peluang individu untuk menjadi jurnalis adalah terdapat berbagai pelatihan tentang jurnalis yang diadakan oleh AJI (Aliansi Jurnalis Independen). Terakhir adalah ancaman bagi individu untuk menjadi jurnalis yaitu individu cenderung kurang 


\section{INTEGRITAS : Jurnal Pengabdian}

Vol 5 No 1 Juli 2021

ISSN 2580 - 7978 (cetak) ISSN 2615 - 0794 (online)

memiliki keberanian dalam mengambil resiko, selain hal tersebut dukungan orang tua dapat menjadi kekuatan maupun kelemahan bagi siswa untuk mewujudkan karir yang telah ditentukan. Adanya dukungan orang tua akan membuat anak termotivasi untuk melanjutkan cita-citanya, sedangkan orang tua yang tidak mendukung karir yang ditentukan oleh anak maka akan menurunkan semangat siswa. Oleh sebab itu pada kegiatan ini di tutup dengan konseling pada orang tua sebagai upaya pemahaman pada orang tua bahwa dukungan dari orang tua kepada anak adalah salah satu dukungan yang cukup penting.

\section{KESIMPULAN}

Kegiatan pengabdian masyarakat dalam bentuk Career Planning and Self Evaluation di Kota Dili, Timor Leste telah dilaksanakan berdasarkan tahapan-tahapan yang telah ditetapkan sebelumnya. Dapat disimpulkan bahwa kegiatan ini telah memberikan pengetahuan tentang career planning dan self evaluation sehingga dapat membantu siswa untuk menentukan karir yang akan dipilih siswa selanjutnya.

Proses career planning and Self Evaluation yang merupakan salah satu kegiatan pengabdian masyarakat perlu dilakukan secara berkelanjutan guna keberlangsungan program pengabdian masyarakat yang fungsinya membantu orang lain mendapatkan kesejahteraan hidup. Kemudian disarankan untuk orang tua agar menerapkan pengetahuan yang telah dijelaskan pada saat konseling orang tua untuk mendukung karir siswa.

\section{DAFTAR PUSTAKA}

Dewa Ketut Sukardi. 1985. Pengantar Pelaksanaan Program dan Konseling di Sekolah. Jakata: Rineke Cipta.

Falentini, F. 2013. Usaha Yang Dilakukan Siswa Dalam Menentukan Arah Pilihan Karir Dan Hambatan Hambatan Yang Ditemui (Studi Deskriptif Terhadap Siswa SMAN 3 Payakumbuh). KONSELOR | Jurnal Ilmiah Konseling. Vol 2, No1.

Hesti. 2017. Jurnalis Timor Leste Membangun Redaksi Independen. Aliansi Jurnalis Independen. https://aji.or.id/read/berita/652/jurnalis-timor-leste-membangunredaksi-independen.html diakses pada Januari 2019

https://kbbi.kemdikbud.go.id/entri/pelatihan diakses pada Januari 2019

Zahroh, Septiani. 2018. Efektivitas Bimbingan Karir Menggunakan Teknik Modeling Simbolik Untuk Meningkatkan Aspek Keterlibatan Kemampuan Perencanaan Karir Peserta Didik. Jurnal Bimbingan dan Konseling Terapan Vol. 02, No. 02 